\title{
Assessment of Some Immune Components from The Bioactive Crude Extract Derived from The Epidermal Mucus of Climbing Perch Anabas Testudines
}

\author{
Agharid al-Rasheed ${ }^{1, *}\left(\mathbb{D}\right.$, Kareem Obayes Handool ${ }^{2}$, Amaal M Alhelli ${ }^{3}$, Bashiru \\ Garba $^{4}$, Belal J Muhialdin ${ }^{5}$, Malihe Masomian ${ }^{6}$, Homayoun Hani ${ }^{7}$, Hassan Hj Mohd \\ Daud $^{8}$
}

\author{
${ }^{1}$ University of Tikrit, Dept. of food science, Faculty of Agriculture, Iraq \\ ${ }^{2}$ Veterinary Directorate, Ministry of Agriculture, Iraq. \\ ${ }^{3}$ Institute of Technology, Technical of water resources, Iraq. \\ ${ }^{4}$ Usmanu Danfodiyo University, Faculty of Veterinary Medicine, Dept. of Veterinary Public Health \& Preventive Medicine Sokoto, Nigeria. \\ ${ }^{5}$ Universiti Putra Malaysia, Faculty of Food Science and Technology, UPM Malaysia, Serdang, Selangor Darul Ehsan. \\ ${ }^{6}$ Universiti Putra Malaysia, Dept. of Microbiology, Faculty of Biotechnology and Biomolecular Sciences, Serdang, Selangor Darul Ehsan. \\ 7 Universiti Putra Malaysia, Faculty of Veterinary Medicine, Dept. of Veterinary Pathology \& Microbiology, Serdang, Selangor Darul Ehsan. \\ ${ }^{8}$ Universiti Putra Malaysia, Faculty of Veterinary Medicine, Dept. of Clinical Studies, Serdang, Selangor Darul Ehsan.
}

\section{Article History}

Received 12 May 2020

Accepted 07 September 2020

First Online 09 September 2020

\section{Corresponding Author}

Tel.: +9647727528703

E-mail: agharidalrasheed@tu.edu.iq

\section{Keywords}

Mucosal immunity

Antimicrobial peptides

Climbing perch

Aquaculture

\begin{abstract}
Fish and other members of the aquatic habitats are usually in constant interaction with their habitat and potentially harmful pathogens. This study was undertaken to evaluate some of the immune components in the bioactive crude obtained from epidermal mucus of climbing perch. The enzyme activities were assessed using the spectrophotometer and turbidometric assay for the lysozyme activity, and while antimicrobial peptides were determined via AKTA Purifier $10 \mathrm{FPLC}$ with a Superdex ${ }^{\mathrm{TM}}$ peptide $10 / 300 \mathrm{GL}$ column and Q-TOF LC/MS for characterization. Likewise, the antibacterial activity against $P$. aeruginosa ATCC 10451 was achieved using chromatography fractions. Results showed that higher activities of lysozyme and protease were present in the crude extract. While values for alkaline phosphatase and esterase activities varied. The data analysis of Q-TOF LC/MS showed apolipoprotein A1 , haemoglobin subunit beta (Fragment), elongation factor 1 -alpha, cytochrome $C$ oxidase subunit1 (Fragment), Beta-actin (Fragment) and potent antimicrobial peptides including de novo AAGPKGPLGPR peptide in crude. This result emphasizes their role in protecting to climbing perch from foreign invaders as a part of the innate immune system throughout the epidermal mucus. The bioactive crude has a high potential to be used as a natural antimicrobial agent for pharmaceutical applications.
\end{abstract}

\section{Introduction}

The innate immune components in fishes are comprised of the mucus layer secreted on the skin, gills, and gastrointestinal tract, as well as the non-specific immune cells (phagocytes and natural killer cells) found in the blood(Subramanian et al., 2007). The skin mucus is an important indicator of the immune competence of fish (Al-Rasheed et al., 2018; Brinchmann, 2016). This is because fish mucus has numerous humoral immune activities(Cordero et al., 2016; Guardiola et al., 2014).
Mucus protects against pathogens and injuriously suspended particles through inhibiting pathogen adherence by sloughing off due to the continuous secretion of the mucus or by providing a repository of many piscine antibacterial proteins and peptides (AMPs) (Subramanian et al., 2007; Uthayakumar et al., 2012). The majority of the antimicrobial peptides are found in specialized peptides with somewhat distinct structures (Rajanbabu \& Chen, 2011). Nevertheless, a large number of peptides occur as larger proteins or protein fragments (Conceição et al., 2012). They include AMP- 
independent anti-infectious substances that ensure the integrity of the skin such as cathepsin B, alkaline phosphatase, complement, transferrin, lysozyme, and C-reactive protein (Cole et al., 1997; X. Zhao et al., 2008). Among small indigenous fishes, Anabas testudines (Bloch, 1972) is an economically important fish in majority of Southern Asian countries (Abdul Halim et al., 2017). The fish is characterized by a thick coat of slime containing mucopolysaccharides, lipids, and proteins, which are essential in keeping the skin moist and this is thought to also enhance the survivability of the fish especially outside the aquatic environment(Agarwal et al., 1980). Anabas is considered to be among the toughest fish with the ability to tolerate very turbid and brackish water conditions(Roberts, 1989; Sakurai et al., 1993). Despite the economic importance of this fish species, literatures on the innate immune components as well as the antibacterial properties of the epidermal mucus have not been fully investigated. Therefore, this study was carried out to assess some innate immune components in fish mucus by evaluating the activity of lysozyme (LYZ), protease, alkaline phosphatase, and esterase enzymes.

\section{Materials and Methods}

\section{Preparation of Bioactive Crude Extract}

The epidermal mucus from climbing perch Anabas testudines (Bloch, 1972) was prepared according to our previous method (Al-Rasheed et al., 2018). Briefly, 15 apparently healthy climbing perch $(18-20 \mathrm{~cm})$ were purchased from local wet market in Seri Kembangan, Serdang, Malaysia and kept in an aerated glass aquarium filled with room temperature pond water for seven days to acclimatize. The epidermal mucus was obtained by subjecting the fish to hypothermic stress as we previously reported (Al-Rasheed et al., 2018). The mucus produced was then scraped and lyophilized at $-80^{\circ} \mathrm{C}$ under vacuum at 0.018 pressure in a lyophilizer. $200 \mathrm{mg}$ of the lyophilized epidermal mucus was mixed with $1 \%$ acetic acid ( $\mathrm{HAc}$ ) in a ratio of 1:4, and heated in a boiling water bath for 3 mins to inhibit proteolytic enzymes activity and solubilize the low-molecular-weight peptides (Conlon, 2007). The heated mixture was completely homogenized with polytron homogenizer on dry ice for $5 \mathrm{~min}$. The resultant homogenate was then centrifuged in a refrigerated centrifuge at 15,000 rpm, for $35 \mathrm{~min}$, at $4^{\circ} \mathrm{C}$ and part of the supernatants of the homogenate was filtered with a Whatman No.1 filter paper size $0.45 \mu \mathrm{m}$ and stored at $4^{\circ} \mathrm{C}$.

\section{Antimicrobial Susceptibility Screening}

The antibacterial activity of the acidic extract was determined by evenly streaking $0.1 \mathrm{ml}$ of bacterial inoculum $\left(10^{5} \mathrm{CFU} / \mathrm{ml}\right)$ on Mueller Hinton agar plate. This is then followed by punching a $6 \mathrm{~mm}$ well in the solid media and $50 \mu$ of the aqueous extract was used to fill up the wells. The plates were then incubated overnight at $37^{\circ} \mathrm{C}$. The antibacterial activity was determined based on the diameter of zone of inhibition. Ciprofloxacin $(15 \mu \mathrm{g} / \mathrm{ml})$ was used as positive control. The antibacterial activity was evaluated against Staphylococcus aureus, Pseudomonas aeruginosa, and Salmonella choleraesuis reference strains as well as local isolates Bacillus subtilis UPMC 1175 and Serratia marcencen S381 (obtained from Institute of Bioscience, Universiti Putra Malaysia).

\section{Enzymes Activity in Bioactive Crude}

The activity of protease, lysozyme, alkaline phosphatase, and esterase were estimated in the bioactive crude $(10 \mathrm{mg} / \mathrm{ml})$ derived from the mucus of the climbing perch.

\section{Protease}

The protease was determined using the substrate azocasein (Sigma) as a sensitive and convenient nonspecific substrate used to quantify the proteolytic activity in bioactive crude. Measurement was done by the release of red colored azopeptides as described by Peres et al (Peres et al., 2014). Briefly, $50 \mathrm{ml}$ of azocasein $(5 \mathrm{mg} / \mathrm{mL}$ ) prepared in $50 \mathrm{mM}$ tris $\mathrm{HCl}$ buffer $(\mathrm{pH}$ 8.0) containing $2 \mathrm{mM} \mathrm{CaCl} 2$, and $50 \mathrm{~mL}$ of the corresponding bioactive crude was incubated at $37^{\circ} \mathrm{C}$ for $1 \mathrm{~h}$. The reaction was stopped by the addition of $100 \mathrm{ml}$ of $5 \%$ (w/v) TCA solution. The mixture was then centrifuged at 10, $000 \mathrm{~g}$ for $5 \mathrm{~min}$ after $10 \mathrm{~min}$ incubation at room temperature. Fifty $(50) \mathrm{mL}$ of the supernatant was mixed with $75 \mathrm{ml}$ of $0.5 \mathrm{M} \mathrm{NaOH}$, and the absorbance was measured at $450 \mathrm{~nm}$ against a blank. One unit (U) of protease activity was defined as a 0.001 increase in absorbance of the assay solution.

\section{Lysozyme (LYZ)}

The turbidimetric assay method described by $\mathrm{Ng}$ et al (Ng et al., 2013) was employed to determine the lysozyme (LYZ) activity in the crude extract by lysis of Gram-positive Micrococcus lysodeikticus. A total of $10 \mu \mathrm{l}$ of bioactive crude and standards of egg white lysozyme (Sigma) respectively, were added in dry cuvettes containing $1.0 \mathrm{~mL}$ of the bacteria. The assay was set to run for $5 \mathrm{~min}$ at $31^{\circ} \mathrm{C}$ and a change in optical density $\mathrm{OD}$ at $450 \mathrm{~nm}$ was recorded at $30 \mathrm{~s}$ intervals, with stirring for $10 \mathrm{~s}$ after each measurement. Range of concentration solutions $(0.1,0.08,0.06,0.04,0.02,0.01$, $0.008,0.006) \mathrm{mg} / \mathrm{ml}$ were prepared from stock solution of $1 \mathrm{mg} / \mathrm{ml}$ which were plotted against the lysozyme activity in OD/min (Dash et al., 2014).

\section{Alkaline Phosphatase (ALP)}

Alkaline phosphatase activity in the bioactive crude was determined spectrophotometrically by the 
dimension clinical chemistry system using the ALP Flex ${ }^{\circledR}$ reagent cartridge (Siemens) according to the manufacturer's instructions. The assay is an in vitro diagnostic test used for the quantitative determination of alkaline phosphatase activity in serum and plasma. The assay uses $p$-nitrophenylphosphate ( $p$-NNP) as a substrate, which will then become catalyzed into $p$ nitrophenol ( $p-N P$ ) by all alkaline phosphatase isoenzymes.

\section{Esterase}

Spectrophotometric assay was also used to detect esterase activity following the hydrolysis of $p$ nitrophenyl myristate (Sigma, St. Louis, MO) at $410 \mathrm{~nm}$ (Guardiola et al., 2014; Ross et al., 2000). For the reaction, $100 \mu \mathrm{l}$ of substrate solution $(25 \mathrm{mM} \mathrm{p}$ nitrophenyl myristate in DMSO) was mixed with $880 \mu \mathrm{l}$ of $50 \mathrm{mM}$ Tris/HCL buffer (pH 7.0) and $20 \mu$ lof bioactive crude. The mixture was incubated for $10 \mathrm{~min}$ at $30^{\circ} \mathrm{C}$ in a shaking water bath at $100 \mathrm{rpm}$ and then $100 \mu \mathrm{l}$ of ethanol was added to stop the reaction. The OD of liberated p-nitrophenol was evaluated at $410 \mathrm{~nm}$. One unit of activity corresponds to the amount of enzyme required to release one $\mathrm{mM}$ of $\mathrm{p}$-nitrophenol product in $1 \mathrm{~min}$, and the activity was expressed as Umg-1 mucus proteins. Esterase activity was determined by referring to the standard curve of $p$-nitrophenol which was plotted using p-nitrophenol standard solution in the range of 0.01-0.3 mM prepared from stock solution of $p$ nitrophenol (Sigma-Aldrich) $10 \mathrm{~mm}$ (Chen et al., 2017).

\section{Isolation of AMPPs by Size Exclusion Chromatography (SEC)}

The isolation of antimicrobial proteins and peptides were conducted by a two-step chromatographic process and $P$. aeruginosa ATCC 10451(Thermo Fisher Scientific, R4607065 Cheng, Melaka, Malaysia) was selected as testing bacteria. In the initial step, a total of $300 \mathrm{~mL}$ crude extract was lyophilized and suspended in $30 \mathrm{~mL}$ sterile distilled water and centrifuged at $15,000 \mathrm{rpm}$ for $15 \mathrm{~min}$ at $4^{\circ} \mathrm{C}$. The suspension was subjected manually to reversed-

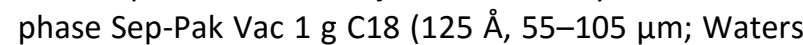
Corporation, WAT036905 MA, USA) by $20-\mathrm{mL}$ plastic syringe as described by Conlon (Conlon, 2007). The cartridge eluate consisting $70 \%$ acetonitrile with $0.1 \%$ Triflouroacetic acid was concentrated to approximately $1.5 \mathrm{ml}$ at room temperature for $60 \mathrm{~min}$. In addition, reducing elute was filtered out using ultrafiltration (UF) advance centrifugal device (MWCO 30kD with Omega Membrane). The filtrates $<30 \mathrm{kDa}$ was loaded onto GE AKTA Purifier 10 FPLC that is equipped with a Superdex 75 10/300 GL column [57]. The column was equilibrated with $50 \mathrm{mM}$ of Sodium phosphate, $\mathrm{pH} 5.8$ in $150 \mathrm{mM} / \mathrm{L}$ of $\mathrm{NaCl}$ buffer at a flow rate of $0.5 \mathrm{~mL} / \mathrm{min}$. The elution profile was monitored at $280 \mathrm{~nm}$ (Song et al., 2012). The inhibitory activity against $P$. aeruginosa ATCC 10145 was accomplished for fractions at three peaks.

\section{Protein and Peptides Profile}

To estimate the profile and molecular weight (MW) of the antimicrobial proteins and peptides, 15\% SDSPAGE was performed as previously described (Laemmli \& Favre, 1973). In this experiment, $20 \mu \mathrm{g}$ of the total protein sample was diluted in a ratio of $1: 1$ with sample buffer containing $(4 \%(\mathrm{w} / \mathrm{v}) \mathrm{SDS}, 50 \mathrm{mM}$ Tris- $\mathrm{HCl}, 2 \%$ mercaptoethanol $(\mathrm{v} / \mathrm{v}), 12 \%(\mathrm{v} / \mathrm{v})$ glycerol, and $0.5 \%$ (w/v) bromophenol blue adjusted with $\mathrm{HCl}$ to $\mathrm{pH} 6.8$, and loaded onto a separating gel of $15 \%$ SDS-under reducing conditions and run in an electrophoresis apparatus for $4 \mathrm{~h}$ at $80 \mathrm{~V}$. Gel stained with Coomassie Brilliant Blue and protein bands were viewed against the protein standard (BioRad) (Hames, 1998).

\section{Identification of Antimicrobial Proteins and Peptides}

The LC-MS/MS technique was carried out to identify the antimicrobial proteins and peptides of climbing perch. The sample was subjected to trypsin digestion, and the identification of proteins and peptides was carried out using Accurate Mass quadruple time-of-flight (Q-TOF) Liquid Chromatography (Agilent 6520, USA) (LC-MS/MS Laboratory/Monash University/Malaysia). Trypsinized sample was injected into (Q-TOF) LC/MSMS to identify the sequence, and the running solvents were $(A) ; 0.1 \%$ formic acid in water and (B) $0.1 \%$ formic acid in acetonitrile. The freeze-dried sample was diluted in $0.75 \mathrm{ml}$ of solvent A. Acquired data were analyzed with PEAKS Studio 8.5, and database search done on the UniProt Anabantaria fasta Database.

\section{Statistical Analysis}

The results were analyzed using SPSS statistical software (version 23). One way analysis of variance used to deduce variability and level of significance $(P<0.05)$. All values were expressed as mean \pm standard error (S.E).

\section{Results}

\section{Antibacterial Activity of Extracts Against Bacteria Isolates}

Evaluation of the antibacterial activity of the acidic mucus extract revealed variable degree of inhibition (Figure 1). The extract prevented the growth of $S$. aureus, $P$. aeruginosa, $S$. choleraesuis, $B$. subtilis UPMC 1175 and S. marcencen S381, however, the difference was only statistically significant for $P$. aeruginosa. Based on the result obtained, the highest zone of inhibition was observed in the plate inoculated with $P$. aeruginosa with a diameter of inhibition (12.65 \pm 0.47$)$. Similarly, $S$. aureus, S. choleraesuis, B. subtilis UPMC 1175, and S. marcencen S381 had $8.5 \pm 0.577,6.75 \pm 0.95,7.25 \pm 1.25$, $6.5 \pm 1.753$, respectively. 


\section{Enzymatic Activities of Bioactive Crude}

The level activities of immune-related enzymes involving protease, lysozyme, alkaline phosphatase, and esterase in the bioactive crude activities are presented in Table 1 . The activity of protease was $213.3 \pm 1.365$ $\mathrm{U} / \mathrm{mg}$, and the concentration and activity level of bioactive crude lysozyme were $0.13 \pm 0.0054 \mu \mathrm{g} / \mathrm{mL}$; $263.25 \pm 18.135 \mathrm{U} / \mathrm{mg}$, respectively. Similarly, alkaline phosphatase and esterase activities had $0.013 \pm 1.35$ $\mathrm{U} / \mathrm{mg}$; and $1.43 \pm 0.033 \mathrm{U} / \mathrm{mg}$, respectively.

\section{Isolation of Antibacterial Fractions by Size-Exclusion Chromatography}

A total of four peaks represented the fractions including peak 1 (fractions: B2-B4, B6-B8, B10-B12), peak 2 (fractions $\mathrm{C} 2-\mathrm{C} 4$ ), peak 3 (fractions: $\mathrm{C} 6-\mathrm{C} 8$ ), and peak 4 (fractions: D2 - D4) (Figure 1). Protein profile of SepPak C18 and Ultrafiltration 30 kDa fraction showed bands with $\mathrm{Mw}$ (25 to $10 \mathrm{kDa}$ ) at 15\% SDS PAGE (Figure 2). However, fractions at peak 1 of Superdex ${ }^{\mathrm{TM}}$ peptide $10 / 300 \mathrm{GL}$ did not show any visible bands on the gel. Antimicrobial activity was sequentially screened for each fraction by using well diffusion agar, and antimicrobial activity against $P$. aeruginosa ATCC10145 has detected at peak 1 fractions eluted between 12.5 to 17.5 mins. Additionally, individual fractions showed equal IZD $(9 \mathrm{~mm})$. Though, IZD of elution fraction of SepPak C18 and Ultrafiltration 30 kDa fraction was 18 $\mathrm{mm}$ (Figure 2).

\section{Q-TOF LC/MS Data Analysis}

Proteins and peptides in the bioactive fractions at peak 1 were identified using Q-TOF LC/MS. Trypsin

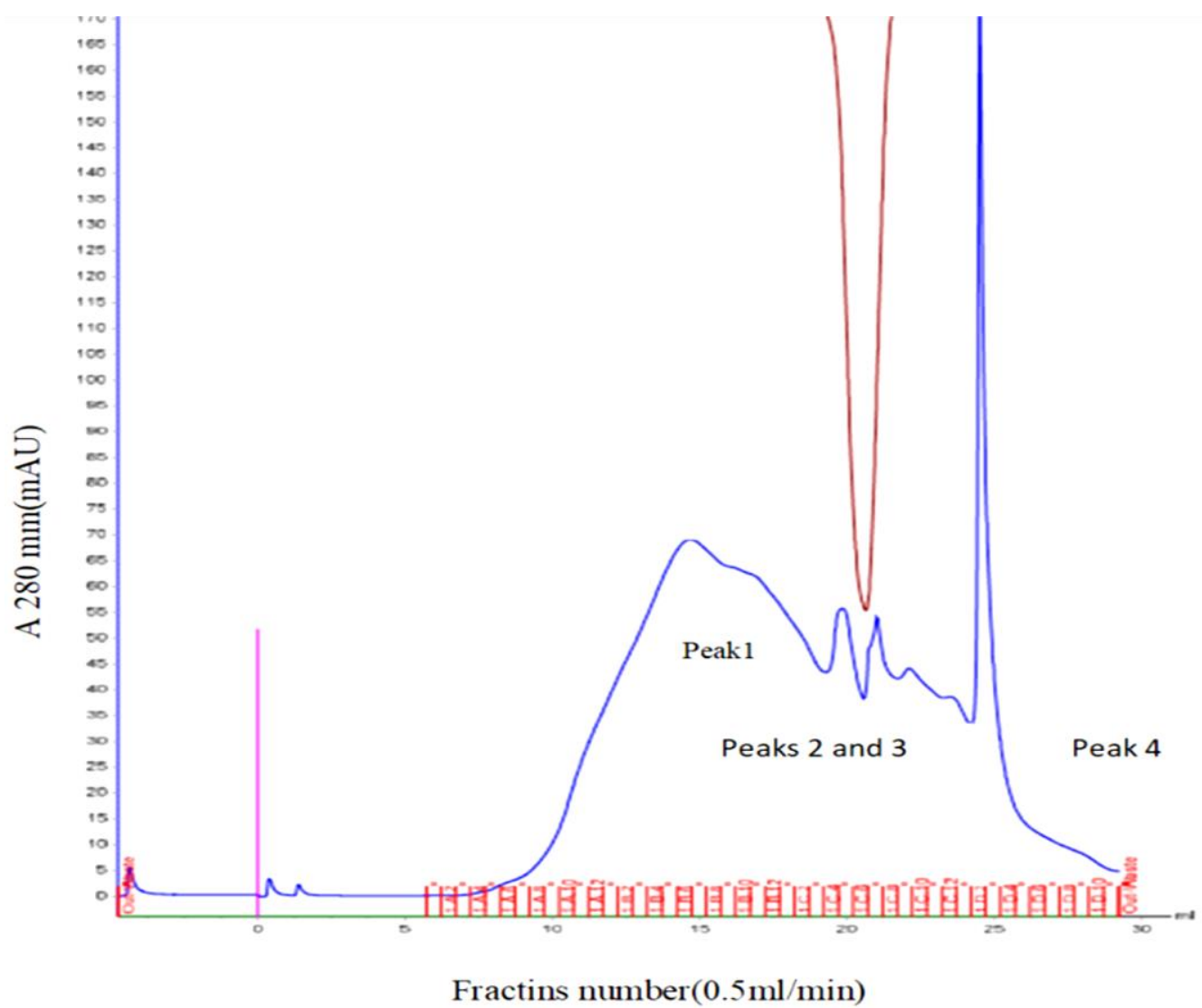

Figure 1. Size-exclusion chromatography of antibacterial proteins and peptides using Superdex ${ }^{\mathrm{TM}}$ peptide $10 / 300 \mathrm{GL}$ on AKTA Purifier 10 FPLC. Four chromatogram peaks; peak 1 (A12-B12), peak 2(C3-C6), peak 3 (C8-C10), and peak 4 (D2-D6) detected by absorbance at $280 \mathrm{~mm}(\mathrm{mAU})$.

Table 1. Enzyme hydrolysate activity of crude of bioactive proteins and peptides

\begin{tabular}{lc}
\hline Parameters & $\mathbf{U} / \mathbf{m g * *}$ \\
\hline Protease & $213.33 \pm 1.365$ \\
Lysozyme & $263.25 \pm 18.135$ \\
Alkaline phosphatase & $0.013 \pm 1.35$ \\
Esterase & $1.43 \pm 0.033$ \\
\hline
\end{tabular}

**U/mg unit of enzyme per $\mathrm{mg}$ in crude cationic proteins and peptides (Mean \pm S.D) 
digestion was applied to reduce the influence of ion suppression effects in Q-TOF LC/MS measurements to obtain more peptide peaks. Subsequently, Q-TOF LC/MS data was analysed using PEAKS Studio 8.5. The analysis results are shown in Table 2.

Proteins in the bioactive crude extract are identified by accession numbers that match with the identified proteins. The arranged and aligned amino acid sequences of apolipoprotein A-1 and haemoglobin subunit beta are shown in Figure 4 a, b. Furthermore, aligned amino acid sequences of proteins, elongation factor alpha, beta -actin and cytochrome c oxidase subunit 1 are shown in Figure 5.

The physical parameters of de novo peptides which were anionic and cationic peptides with mass ranging from 1020.25 to $1902.06 \mathrm{Da}$ with different hydrophobicity ratios, and residues of amino acids are shown in Table 3. Similarly, the MS/MS spectrum of de novo peptide AAGPKGPLGPR is shown in Figure 3 and the MS/MS spectra of other peptides detected are presented in Figure 6. All proteins and peptides were analysed from UniProt database.

\section{Discussion}

The present study was able to demonstrate the potentials of the bioactive crude obtained from climbing perch for use as an alternative antimicrobial agent especially in the current situation where most infectious disease pathogens are developing resistance to the conventional drugs.Although, in this study the extract was able to exert considerable antibacterial activity on all the bacterial organisms tested by preventing their growth, statistically significance was observed only for $P$. aeroginosa. The fact that the acidic mucus extract was able to prevent the growth of the bacterial organisms

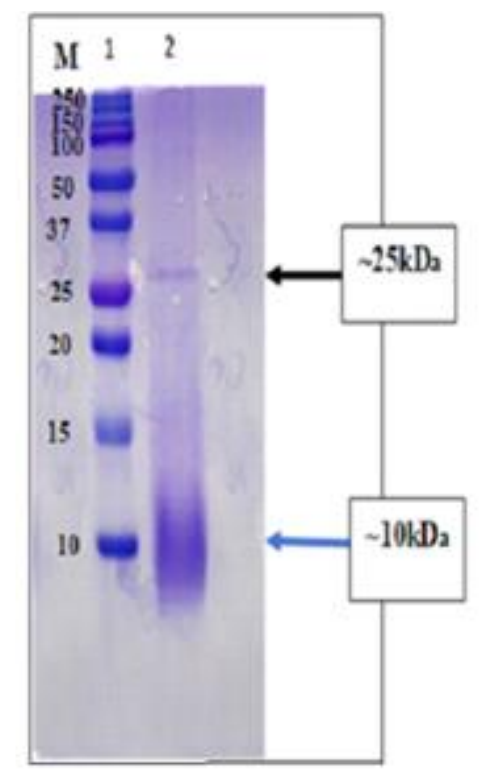

Figure 2. SDS-PAGE (15\%) analysis of elution fraction form SepPak C18 and ultrafiltration $30 \mathrm{kDa}$. Line 1 is the calibrated high protein marker (BioRad), and lane 2 represents the protein profile of fraction; arrows indicate the bands of fraction proteins.

Table 2. Q-TOF LC/MS analysis details, accession number, and physical parameters of identified proteins in the bioactive fraction of Superdex ${ }^{\mathrm{TM}}$ peptide $10 / 300 \mathrm{GL}$

\begin{tabular}{|c|c|c|c|c|}
\hline Protein name & Accession No. & Peptides & Unique peptides & $\%$ protein coverage \\
\hline $\begin{array}{l}\text { Apolipoprotein A-1 } \\
\text { Channa striata }\end{array}$ & А0А077H3Р6 & 22 & 22 & 44 \\
\hline $\begin{array}{l}\text { Beta-actin (Fragment) } \\
\text { Channa argus } \times \text { Channa maculata }\end{array}$ & AOAOU2KOIO & 6 & 0 & 34 \\
\hline $\begin{array}{l}\text { Beta-actin (Fragment) } \\
\text { Channa punctata }\end{array}$ & F2YRP1 & 6 & 0 & 34 \\
\hline $\begin{array}{l}\text { Hemoglobin subunit beta } \\
\text { Channa striata }\end{array}$ & V9QM19 & 5 & 5 & 20 \\
\hline $\begin{array}{l}\text { Elongation factor 1-alpha (Fragment) } \\
\text { Channa maculata }\end{array}$ & A0A1W5YI2 & 7 & 5 & 12 \\
\hline $\begin{array}{l}\text { Cytochrome c oxidase subunit1 (Fragment) } \\
\text { Anabas testudineus }\end{array}$ & A0A159YN20 & 2 & 0 & 5 \\
\hline $\begin{array}{l}\text { Cytochrome c oxidase subunit } 1 \text { (Fragment) } \\
\text { Anabas testudineus }\end{array}$ & A0A1B1RVD3 & 2 & 0 & 5 \\
\hline
\end{tabular}




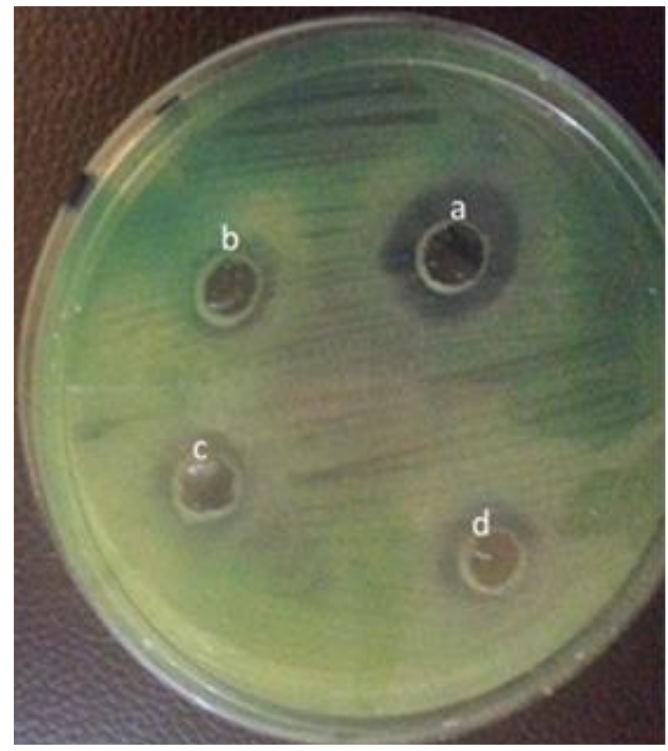

Figure 3. Mueller-Hinton agar plate showing well diffusion assay (zone of inhibition measured in $\mathrm{mm}$ ) against $P$. aeruginosa ATCC 10145 for (a) fraction for SepPak C18 and ultrafiltration 30 kDa and fractions at peak 1 (b) B2-B4, (c) B6-B8, and (d) B10-B12 for Superdex ${ }^{\mathrm{TM}}$ peptide $10 / 300 \mathrm{G}$.

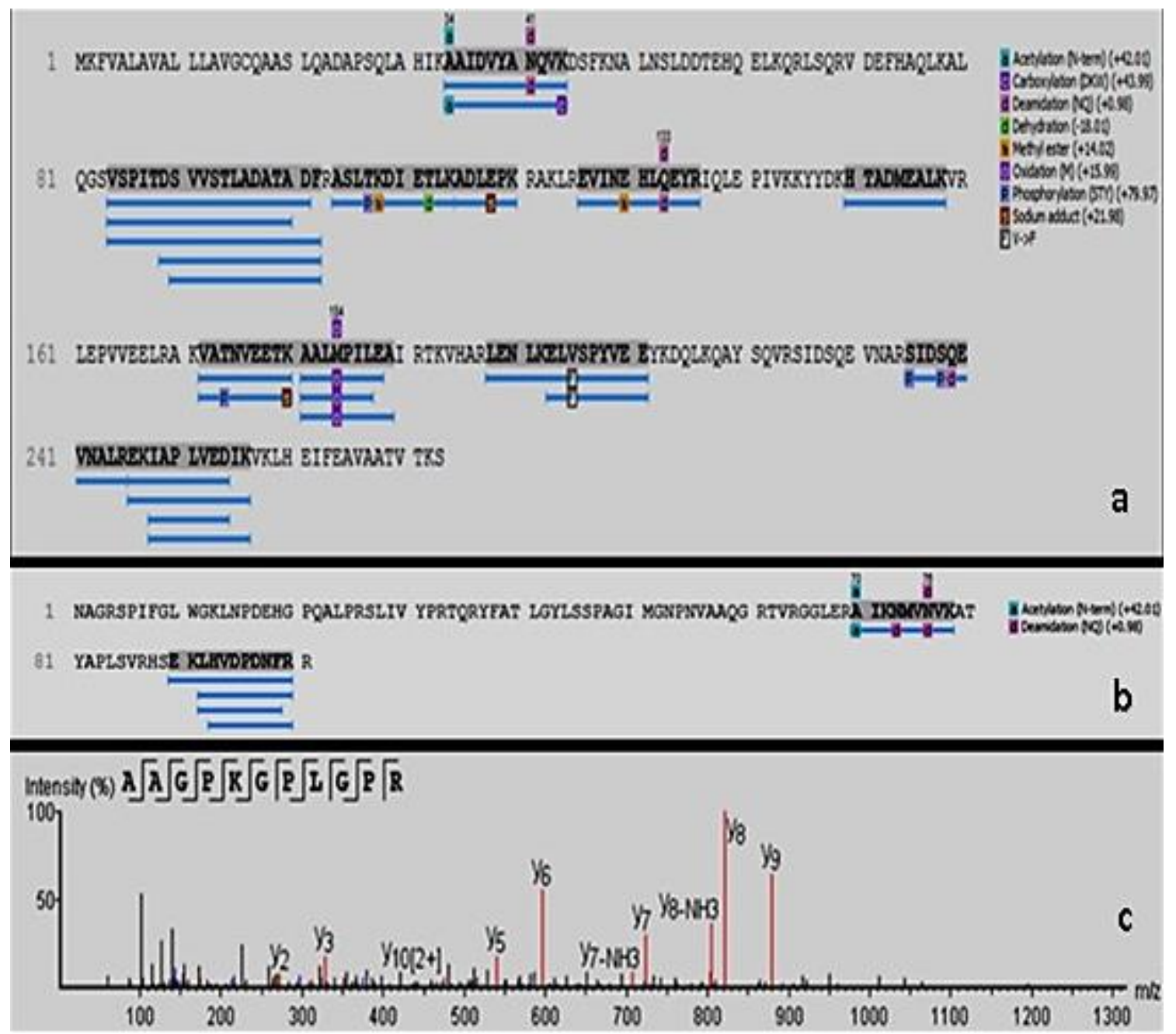

Figure 4. (a) Aligned amino acid sequences (blue) coverage of apolipoprotein A-1 of bioactive fraction, matched with identified apolipoprotein A-1 from Channa striata; (b) Haemoglobin subunit beta of bioactive fractions matched with peptide sequence of identified haemoglobin subunit beta from of bioactive fractions matched with peptide sequence of identified haemoglobin subunit beta from Channa argus and Channa maculata; (c) MS/MS spectrum of de novo peptide AAGPKGPLGPR showing the fragmentation pattern of the peptide with a parent mass of 1020.25 and doubly charged. 


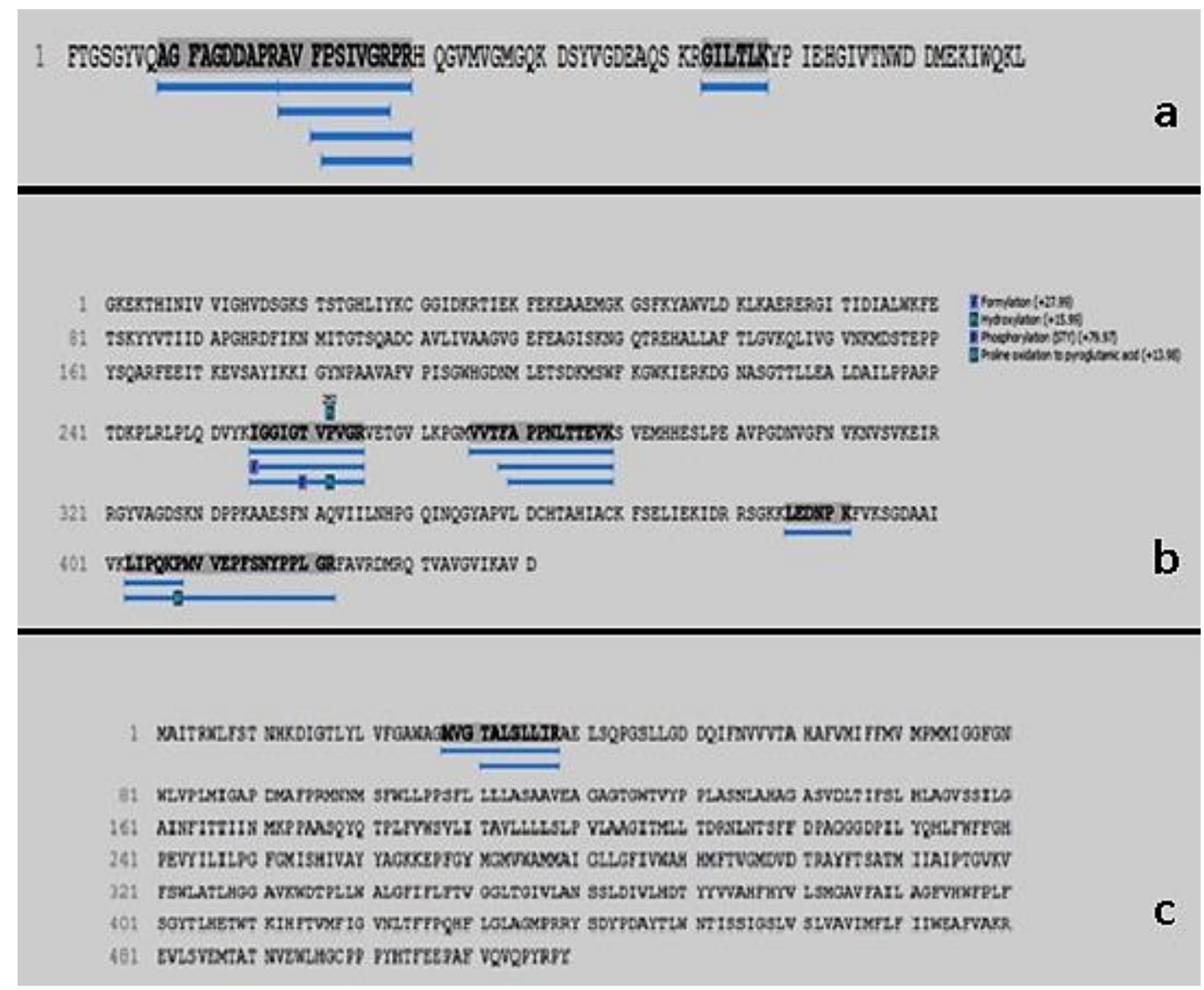

Figure 5. (a) Aligned amino acid sequences (blue) coverage of elongation factor alpha of bioactive fraction, matched with identified elongation factor from Channa mulculata; (b) Beta-actin of bioactive fraction matched with beta-actine from Channa punctata; (c) Cytochrome $\mathrm{C}$ oxidase subunit 1 of bioactive fraction matched with cytochrome $\mathrm{C}$ oxidase of bioactive of Channa punctata.

Table 3. Sequences of De novo peptides in the biological active fraction

\begin{tabular}{lllll}
\hline Peptide sequence & Residues & Hydrophobicity ratio & Net charge & M.W (Dalton) \\
\hline WTGPSGLTGFLQQR & 14 & 28.2 & +1 & 1547.71 \\
LLLNGGGSADSVDTPASALK & 20 & 40 & -1 & 1886 \\
LNGGGSADSVDTPASALK & 18 & 33.3 & -1 & 1659.75 \\
SVPQQQLKSSVDEEVTK & 17 & 23.53 & -1 & 1902.06 \\
AAGPKGPLGPR & 11 & 27 & +2 & 1020.25 \\
\hline
\end{tabular}

The data of de novo peptides were analyzed using APD3: Antimicrobial Peptide Predictor at http://aps.unmc.edu/AP/prediction/prediction_main.php

tested is an indication that they possess some antibacterial properties. The inhibitory effect of acidity crude extract may be due to the ability of the cationic antibacterial peptides and proteins to penetrate host tissues via pores created by pathogenic bacteria (Bragadeeswaran et al., 2011). This suggests that fish secrete antibacterial proteins and peptides that are able to permeabilize the membrane of the target cell and thus acts (same word repeated) as a defense barrier (Ravichandran et al., 2010). Moreover, the extraction using mild acid solution of $1 \%$ of acetic acid may have increased the soluble cationic peptides and proteins in acidic medium which have broad-spectrum bactericidal activity against a wide range of pathogens (Hancock \& Sahl, 2006). The findings in this study showed that; protease activity in the bioactive crude extract of climbing perch was three-fold higher than the activity of protease in skin mucus extract of olive flounder (Paralichthys olivaceus) (Jung et al., 2012; Palaksha et al., 2008). The high activity of protease indicates a potential role in the prevention of colonization by pathogenic organisms on the skin of climbing perch, which is similar to an earlier report by Marcos-López et al. (Marcos-López et al., 2017). Similarly, the presence of lysozyme with activity $263.25 \mathrm{U} / \mathrm{mg}$ was found to be high compared to the epidermal mucus of freshwater fish Caspian kutum (Rutilus frisii kutum) and snakehead fish Channa striatus as well as hagfish Myxine glutinosa (Arulprakash et al., 2013; Bragadeeswaran et al., 2011; Heidari \& Farzadfar, 2017). While the concentration of lysozyme in bioactive crude was lower than skin mucus LYZ activity of Indian major carps C. catla (Dash et al., 2014). The high (LYZ) activity in seawater species was similar to LYZ activity in the bioactive crude as previously 


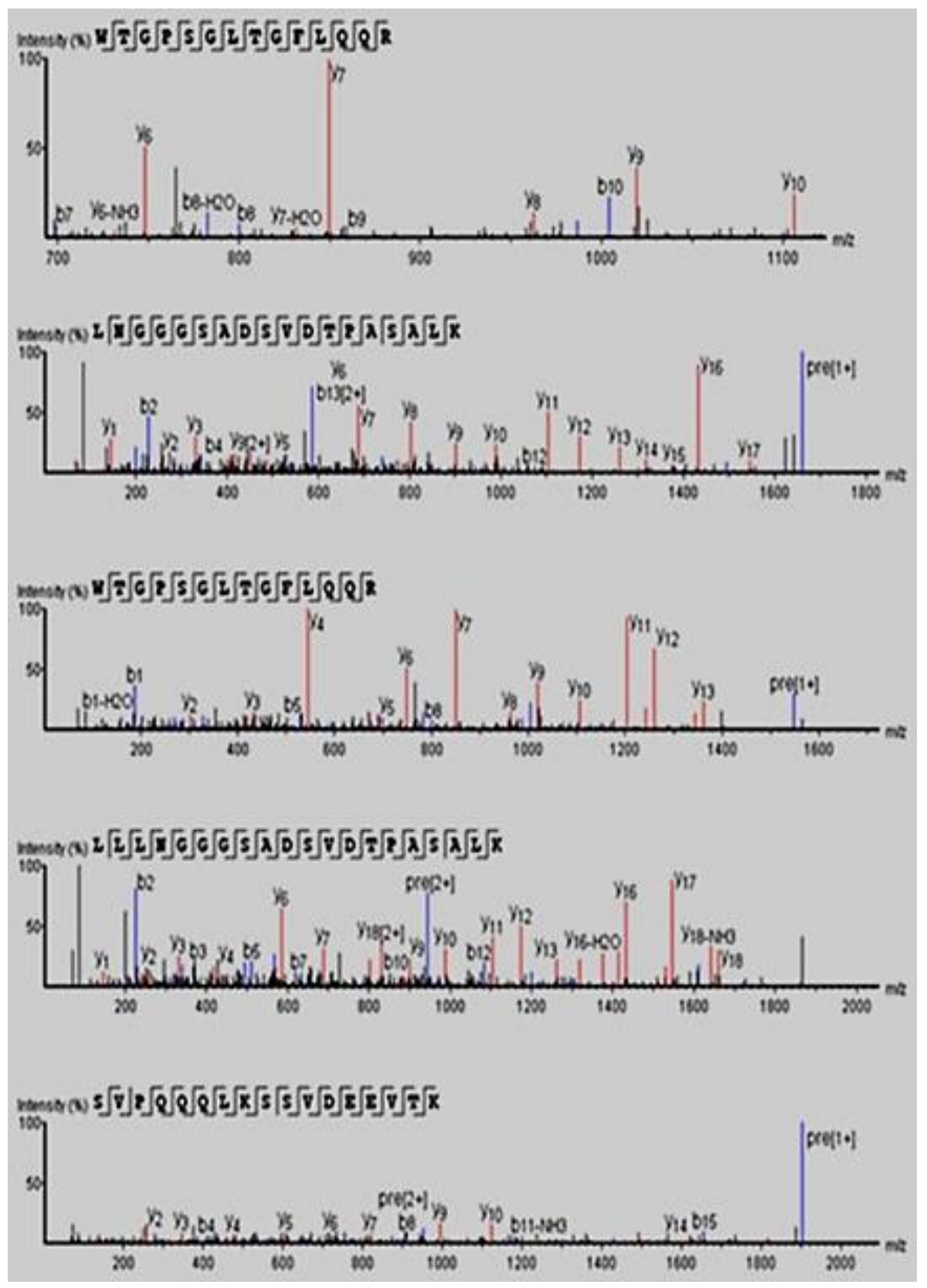

Figure 6. MS/MS spectrum of de novo peptides showing the fragmentation pattern of peptide WTGPSGLTGFLQQR, LLLNGGGSADSVDTPASALK, LNGGGSADSVDTPASALK and SVPQQQLKSSVDEEVTK

mentioned based on their species-specific evolutionary adaptation to different environmental conditions (Dash et al., 2014). This is likely because the fish an obligate air-breathing fish with the ability to walk on the ground for long periods, thus indicates skin resistance to external invasion (Kasi Marimuthu, Jeevanand Arumugam, 2009).

The precise function of ALP is that it act as a potential stress indicator. Elevation in the specific APL activity had been observed in fish epidermal mucus following the physical, chemical and microbial stress (Bezerra et al., 2014; Iger \& Abraham, 1990, 1997). However, the activity of ALP in bioactive crude in this present study was lower than ALP in the skin mucus of freshwater snakehead fish Channa striatus. The disparity may be attributed to the characteristic $\mathrm{pH}$ optimum condition, broad substrate specificity or the storage effect (Cordero et al., 2016). Esterase in the skin mucus of fish may play a significant role in the innate immune response against pathogenic microorganisms (Bragadeeswaran et al., 2011). Bioactive crude extract obtained from climbing perch showed higher esterase activity than epidermal mucus of freshwater snakehead fish Channa striatus (Arulprakash et al., 2013). With regards to the antimicrobial proteins and peptides, elution fraction from Ultrafiltration $30 \mathrm{kDa}$ exhibited more antibacterial activity on P. aeruginosa ATCC 10145 in comparison to the Superdex ${ }^{\mathrm{TM}}$ peptide $10 / 300 \mathrm{GL}$ chromatography fraction, indicating possible synergistic action between protein components. 
The LC-MS/MS in recent advances of proteomics research methods have been used for the identification and quantification of proteins in the mucus of fish (Cordero et al., 2016). Digestion fraction of Superdex ${ }^{\mathrm{TM}}$ peptide $10 / 300 \mathrm{GL}$ was run through Q-TOF LC/MS, and a high number of suitable peptides were generated. Although, only the fragmented and matched information in the database of parameters UniProt, Anabantaria fasta sequence was selected. There is limited information about epidermal mucus and the epidermal protein of climbing perch (Anabas testudenius). This study was able to demonstrate for the first time that apolipoprotein A-1 was derived from epidermal mucus of climbing perch. It was matched with apolipoprotein A-1 of Channa striata. Previous reports indicate that the protein is up-regulated in the skin mucus of sea lice infected Atlantic salmon (Easy \& Ross, 2009). Moreover, apolipoprotein A1 has also been identified in the skin mucus of naïve European sea bass (Rajan et al., 2011). Furthermore, proteomic analysis of the mucosal proteins of lumpsucker (Cyclopterus lumpus) revealed the presence of apolipoprotein A-1 and are thought to be involved in immune or stress responses (Patel \& Brinchmann, 2017). In channel catfish, this protein also showed lytic activities against Gram-positive Micrococcus lysodeikticus and Gramnegative Aeromonas hydrophila (Pridgeon \& Klesius, 2013). Additionally, studies have also reported a possible role of apolipoprotein $A-I$ in enhancing the neutralization of other toxic bacterial products, such as lipoteichoic acid (Johnston et al., 2008). Other components of the crude mucus detected in this study are; hemoglobin subunit beta (Fragment) which was found to match with hemoglobin subunit beta (Fragment) of Channa striata. The identification of this fragment in the bioactive crude was novel and been reported for the first time. The protein corresponds to the haemoglobin B-chain was identified previously from Monopterus albus. haemoglobin, which is a cationic protein, which is made up of twin $\alpha$ and $\beta$ globin subunits ( $\alpha 2 \& \beta 2$ ) (Yi et al., 2017). In addition to their oxygen-carrying capacities, they also have immunological properties. However, many proteolytically generated hemoglobin-derived bioactive peptides have shown potent activities toward many pathogenic microorganisms (Yi et al., 2017). This study for the first time demonstrated Elongation factor 1alpha in bioactive crude from epidermal mucus of climbing perch (Anabas testudineus). It is a member of the $G$ protein family, and one of the four subunits that compose the eukaryotic elongation factor 1 involved in the regulation of peptide synthesis identified from European sea bass (Dicentrarchus labrax) (Infante et al., 2008). Moreover, cytochrome C oxidase subunit1 (Fragment) which has been previously recorded in the complete mitochondrial genome of the Anabas testudineus, including cytochrome c oxidase was also identified (H. Zhao et al., 2016). However, this was the first time to identify cytochrome $\mathrm{C}$ oxidase subunit1 in bioactive crude derived from epidermal mucus of climbing perch (Anabas testudineus). However, cytochrome $\mathrm{C}$ oxidase subunit1 (Fragment) has been earlier identified in the skin mucus of gilthead seabream (Sparus aurata) (Pérez-Sánchez et al., 2017).

$\beta$-actin is a dynamic and structural protein that plays important roles during phagocytosis and cell motility cytokinesis and cytoplasmic streaming (Brinchmann, 2016; Patel \& Brinchmann, 2017). This study also demonstrated Beta-actin (Fragment) in bioactive crude from epidermal mucus of climbing perch (Anabas testudineus) and the protein matched with Beta-actin (Fragment) of Channa argus $\mathrm{x}$ Channa maculate and Channa punctate. Similarly, previous studies have shown that actin fragments have been identified in the skin mucus of sea lice (Lepeophtheirus salmonis), infected Atlantic salmon (Salmo salar) and in the skin mucus of lumpsucker (Cyclopterus lumpus).

Peptides with a negative charge are potentially anionic antimicrobial peptides as reported by Harris et al. (Harris et al., 2009). Some of these peptides were used as metal ions to form cationic salt bridges to interact with the negative charge of bacteria. The de novo peptide AAGPKGPLGPR identified in this study was selected among other peptides predicted to be antibacterial peptides depending on its net charge (+2) and low residues as well as its hydrophobic ratio (27\%). Most of the identified AMPs are relatively short comprising of about 10-50 amino acid residues. They generally have an overall positive charge ranging from +2 to +11 and contain a substantial proportion of hydrophobic residues (Hancock \& Sahl, 2006; Pasupuleti et al., 2012; Yeaman \& Yount, 2003). Amino acid composition of AAGPKGPLGPR peptide was low - Ala Gly - Pro - Lys - Gly - Pro - Leu - Gly - Pro - Arg) rich in Proline $27 \%$ and Gly $27 \%$. Unlike other forms of AMPs, Proline-rich antimicrobial peptides (PR-AMPs) act differently via a distinctive 'non-lytic' mechanisms. They penetrate microbial membranes without disrupting the membrane integrity, and then bind to and interact with the specific intracellular targets (Cao et al., 2015).

Similar to the findings in this study, antimicrobial peptides have been demonstrated previously from Misgurnus anguillicaudatus, Pardachirus marmoratus and Pardachirus pavoninus (Lazarovici et al., 1986; Liang et al., 2011). This may be because they are all teleost fish characterized by a labyrinth organ that allows them to breath air while outside their aquatic environment as well as the adaptation to travel across land especially when their habitat becomes inhospitable. The mucus layers of these fishes are composed of many enzymes and antimicrobial proteins, which are thought to be involved in the innate immunity of the fish (Haniffa et al., 2014). The components of the mucus are also thought to function in the cytoplasm against intracellular pathogens in addition to many proteins that exert strong resistance to invading pathogens, including the lipoproteins A-1 observed in the present study (Concha et al., 2003). 


\section{Conclusion}

This study provides for first time proteomic analysis of bioactive crude derived from epidermal mucus of climbing perch. Apolipoprotein A-1, and haemoglobin subunit beta were the major proteins detected from the mucus extract, in addition to de novo peptides derived from crude were detected. Other identified proteins, including Beta-actin, Elongation factor 1-alpha and cytochrome c-oxidase subunit1. These results emphasize their role in protecting climbing perch from foreign invaders as a part of the innate immune system throughout the epidermal mucus. A high-resolution mass spectrometry-based proteomic approach was able to identify proteins in the crude extract. These outcomes may serve an opening to further investigations to determine the potential medical application of bioactive proteins and peptides in crude in the development of protection assays as well as recombinant protein fractions that may be suitable in developing diagnostic kits for future use.

\section{Acknowledgements}

The authors wish to thank Miss Farahayu and Miss Azira of the Malaysia Genome Institute, as well as Miss Tee at LCMS Laboratory, Monash University Malaysia for their kind assistance.

\section{References}

Abdul Halim, M., Nabi, M., Nahar Director, S., \& Md Abdul Halim, C. (2017). Study on optimization of stocking density of climbing perch (Anabas testudineus, Bloch 1792) in marginal farmer earthen ponds. Journal of Entomology and Zoology Studies JEZS, 5(53), 833-837.

Agarwal, S. K., Banerjee, T. K., \& Mittal, A. K. (1980). A histochemical study of the epidermis of the climbing perch, Anabas testudineus (Anabantidae, Pisces). Zeitschrift Fur Mikroskopisch-Anatomische Forschung, 94(1), 143-159.

Al-Rasheed, A., Handool, K. O., Garba, B., Noordin, M. M., Bejo, S. K., Kamal, F. M., \& Daud, H. H. M. (2018). Crude extracts of epidermal mucus and epidermis of climbing perch Anabas testudineus and its antibacterial and hemolytic activities. The Egyptian Journal of Aquatic Research, 44(2), 125-129.

Arulprakash, L. K., Prakash M, \& Senthilraja P. (2013). Lysozyme, Protease, Alkaline phosphatase and Esterase activity of epidermal skin mucus of freshwater snake head fish Channa striatus. International Journal of Research in Pharmaceutical and Biosciences, 3(1), 17-20.

Bezerra, R. F., Soares, M. do C. F., Santos, A. J. G., Carvalho, M., Matoso, E. V., \& Coelho, L. C. B. B. (2014). Seasonality influence on biochemical and hematological indicators of stress and growth of Pirarucu (Arapaima gigas), an Amazonian air-breathing fish. The Scientific World Journal, 2014.

Bragadeeswaran, S., Priyadharshini, S., Prabhu, K., \& Rani, S. R. S. (2011). Antimicrobial and hemolytic activity of fish epidermal mucus Cynoglossus arel and Arius caelatus. Asian Pacific Journal of Tropical Medicine, 4(4), 305-309.
https://doi.org/10.1016/S1995-7645(11)60091-6

Brinchmann, M. F. (2016). Immune relevant molecules identified in the skin mucus of fish using -omics technologies. Molecular BioSystems, 12(7), 2056-2063. https://doi.org/10.1039/c5mb00890e

Cao, H., Ke, T., Liu, R., Yu, J., Dong, C., Cheng, M., Huang, J., \& Liu, S. (2015). Identification of a Novel Proline-Rich Antimicrobial Peptide from Brassica napus. PLOS ONE, 10(9), e0137414. https://doi.org/10.1371/journal.pone.0137414

Chen, T., Li, Y., \& Zhang, L. (2017). Nine Different Chemical Species and Action Mechanisms of Pancreatic Lipase Ligands Screened Out from Forsythia suspensa Leaves All at One Time. Molecules, 22(5), 795. https://doi.org/10.3390/molecules22050795

Coates, C. J., \& Decker, H. (2017). Immunological properties of oxygen-transport proteins: hemoglobin, hemocyanin and hemerythrin. Cellular and Molecular Life Sciences, 74(2), 293-317.

Cole, A. M., Weis, P., \& Diamond, G. (1997). Isolation and characterization of pleurocidin, an antimicrobial peptide in the skin secretions of winter flounder. The Journal of Biological Chemistry, 272(18), 12008-12013. https://doi.org/10.1074/JBC.272.18.12008

Conceição, K., Monteiro-dos-Santos, J., Seibert, C. S., Ismael Silva, P., Marques, E. E., Richardson, M., \& LopesFerreira, M. (2012). Potamotrygon cf. henlei stingray mucus: Biochemical features of a novel antimicrobial protein. Toxicon, 60(5), 821-829. https://doi.org/10.1016/j.toxicon.2012.05.025

Concha, M. I., Molina, S., Oyarzún, C., Villanueva, J., \& Amthauer, R. (2003). Local expression of apolipoprotein A-I gene and a possible role for HDL in primary defence in the carp skin. Fish \& Shellfish Immunology, 14(3), 259273. https://doi.org/10.1006/FSIM.2002.0435

Conlon, J. M. (2007). Purification of naturally occurring peptides by reversed-phase HPLC. Nature Protocols, 2(1), 191-197. https://doi.org/10.1038/nprot.2006.437

Cordero, H., Brinchmann, M. F., Cuesta, A., Meseguer, J., \& Esteban, M. A. (2015). Skin mucus proteome map of European sea bass (Dicentrarchus labrax). PROTEOMICS, 15(23-24), 4007-4020. https://doi.org/10.1002/pmic.201500120

Cordero, H., Cuesta, A., Meseguer, J., \& Esteban, M. Á. (2016). Changes in the levels of humoral immune activities after storage of gilthead seabream (Sparus aurata) skin mucus. Fish \& Shellfish Immunology, 58, 500-507. https://doi.org/10.1016/j.fsi.2016.09.059

Dash, S., Samal, J., \& Thatoi, H. (2014). A comparative study on innate immunity parameters in the epidermal mucus of Indian major carps. Aquaculture International, 22(2), 411-421. https://doi.org/10.1007/s10499-013-9649-2

Easy, R. H., \& Ross, N. W. (2009). Changes in Atlantic salmon (Salmo salar) epidermal mucus protein composition profiles following infection with sea lice (Lepeophtheirus salmonis). Comparative Biochemistry and Physiology Part D: Genomics and Proteomics, 4(3), 159-167. https://doi.org/10.1016/j.cbd.2009.02.001

Guardiola, F. A., Cuesta, A., Abellán, E., Meseguer, J., \& Esteban, M. A. (2014). Comparative analysis of the humoral immunity of skin mucus from several marine teleost fish. Fish \& Shellfish Immunology, 40(1), 24-31. https://doi.org/10.1016/j.fsi.2014.06.018

Hames, B. D. (1998). Gel electrophoresis of proteins: a practical approach (Vol. 197). OUP Oxford. 
Hancock, R. E. W., \& Sahl, H.-G. (2006). Antimicrobial and hostdefense peptides as new anti-infective therapeutic strategies. Nature Biotechnology, 24(12), 1551-1557. https://doi.org/10.1038/nbt1267

Haniffa, M. A., Viswanathan, S., Jancy, D., Poomari, K., Manik, S., \& an. (2014). International Research Journal of Microbiology. International Research Journal of Microbiology, 5(2), 22-27. https://doi.org/10.14303/irjm.2014.013

Harris, F., Dennison, S. R., \& Phoenix, D. A. (2009). Anionic antimicrobial peptides from eukaryotic organisms. Current Protein \& Peptide Science, 10(6), 585-606.

Heidari, B., \& Farzadfar, F. (2017). Effects of temperature and gonadal growth on the lysozyme level of immune tissues in the male and female Caspian kutum (Rutilus frisii kutum). Aquaculture Research, 48(2), 377-385. https://doi.org/10.1111/are.12886

Iger, Y., \& Abraham, M. (1990). The process of skin healing in experimentally wounded carp. Journal of Fish Biology, 36(3), 421-437. https://doi.org/10.1111/j.10958649.1990.tb05622.x

Iger, Y., \& Abraham, M. (1997). Rodlet cells in the epidermis of fish exposed to stressors. Tissue and Cell, 29(4), 431438.

Infante, C., Asensio, E., Cañavate, J. P., \& Manchado, M. (2008). Molecular characterization and expression analysis of five different elongation factor 1 alpha genes in the flatfish Senegalese sole (Solea senegalensis Kaup): differential gene expression and thyroid hormones dependence during metamorphosis. BMC Molecular Biology, 9(1), 19.

Johnston, L. D., Brown, G., Gauthier, D., Reece, K., Kator, H., \& Van Veld, P. (2008). Apolipoprotein Al from striped bass (Morone saxatilis) demonstrates antibacterial activity in vitro. Comparative Biochemistry and Physiology Part B: Biochemistry and Molecular Biology, 151(2), 167-175.

Jung, T. S., del Castillo, C. S., Javaregowda, P. K., Dalvi, R. S., Nho, S. W., Park, S. Bin, Jang, H. Bin, Cha, I. S., Sung, H. W., Hikima, J., \& Aoki, T. (2012). Seasonal variation and comparative analysis of non-specific humoral immune substances in the skin mucus of olive flounder (Paralichthys olivaceus). Developmental \& Comparative Immunology, 38(2), 295-301. https://doi.org/10.1016/j.dci.2012.06.005

Kasi Marimuthu, Jeevanand Arumugam, D. S. and R. J. (2009). Studies on the Fecundity of Native Fish Climbing Perch (Anabas Testudineus, Bloch) in Malaysia. AmericanEurasian Journal of Sustainable Agriculture, 3(3), 266274.

Kravitz, M. S., Pitashny, M., \& Shoenfeld, Y. (2005). Protective Molecules-C-Reactive Protein (CRP), Serum Amyloid $P$ (SAP), Pentraxin3 (PTX3), Mannose-Binding Lectin (MBL), and Apolipoprotein A1 (Apo A1), and Their Autoantibodies: Prevalence and Clinical Significance in Autoimmunity. Journal of Clinical Immunology, 25(6), 582-591. https://doi.org/10.1007/s10875-005-7828-2

Laemmli, U. K., \& Favre, M. (1973). Maturation of the head of bacteriophage T4: I. DNA packaging events. Journal of Molecular Biology, 80(4), 575-599.

Lazarovici, P., Primor, N., \& Loew, L. M. (1986). Purification and pore-forming activity of two hydrophobic polypeptides from the secretion of the Red Sea Moses sole (Pardachirus marmoratus). The Journal of Biological Chemistry, 261(35), 16704-16713.
Liang, Y., Guan, R., Huang, W., \& Xu, T. (2011). Isolation and Identification of a Novel Inducible Antibacterial Peptide from the Skin Mucus of Japanese Eel, Anguilla japonica. The Protein Journal, 30(6), 413-421. https://doi.org/10.1007/s10930-011-9346-9

Liepke, C., Baxmann, S., Heine, C., Breithaupt, N., Ständker, L., \& Forssmann, W.-G. (2003). Human hemoglobin-derived peptides exhibit antimicrobial activity: a class of host defense peptides. Journal of Chromatography B, 791(12), 345-356. https://doi.org/10.1016/S1570-0232(03)00245-9

Marcos-López, M., Espinosa Ruiz, C., Rodger, H. D., O'Connor, I., MacCarthy, E., \& Esteban, M. Á. (2017). Local and systemic humoral immune response in farmed Atlantic salmon (Salmo salar L.) under a natural amoebic gill disease outbreak. Fish \& Shellfish Immunology, 66, 207216. https://doi.org/10.1016/j.fsi.2017.05.029

Marimuthu, K., Arumugam, J., Sandragasan, D., \& Jegathambigai, R. (2009). Studies on the fecundity of native fish climbing perch (Anabas testudineus, Bloch) in Malaysia. American-Eurasian Journal of Sustainable Agriculture, 3(3), 266-274.

Ng, A., Heynen, M., Luensmann, D., Subbaraman, L. N., \& Jones, L. (2013). Optimization of a Fluorescence-based Lysozyme Activity Assay for Contact Lens Studies. Current Eye Research, 38(2), 252-259. https://doi.org/10.3109/02713683.2012.757324

Palaksha, K. J., Shin, G.-W., Kim, Y.-R., \& Jung, T.-S. (2008). Evaluation of non-specific immune components from the skin mucus of olive flounder (Paralichthys olivaceus). Fish \& Shellfish Immunology, 24(4), 479-488. https://doi.org/10.1016/J.FSI.2008.01.005

Pasupuleti, M., Schmidtchen, A., \& Malmsten, M. (2012). Antimicrobial peptides: key components of the innate immune system. Critical Reviews in Biotechnology, 32(2), 143-171. https://doi.org/10.3109/07388551.2011.594423

Patel, D. M., \& Brinchmann, M. F. (2017). Skin mucus proteins of lumpsucker (Cyclopterus lumpus). Biochemistry and Biophysics Reports, 9, 217-225. https://doi.org/10.1016/J.BBREP.2016.12.016

Peres, C. M., Alves, M., Hernandez-Mendoza, A., Moreira, L., Silva, S., Bronze, M. R., Vilas-Boas, L., Peres, C., \& Malcata, F. X. (2014). Novel isolates of lactobacilli from fermented Portuguese olive as potential probiotics. LWT-Food Science and Technology, 59(1), 234-246.

Pérez-Sánchez, J., Terova, G., Simó-Mirabet, P., Rimoldi, S., Folkedal, O., Calduch-Giner, J. A., Olsen, R. E., \& SitjàBobadilla, A. (2017). Skin Mucus of Gilthead Sea Bream (Sparus aurata L.). Protein Mapping and Regulation in Chronically Stressed Fish. Frontiers in Physiology, 8, 34. https://doi.org/10.3389/fphys.2017.00034

Pridgeon, J. W., \& Klesius, P. H. (2013). Apolipoprotein A1 in channel catfish: Transcriptional analysis, antimicrobial activity, and efficacy as plasmid DNA immunostimulant against Aeromonas hydrophila infection. Fish \& Shellfish Immunology, 35(4), 1129-1137. https://doi.org/10.1016/j.fsi.2013.07.028

Rajan, B., Fernandes, J. M. O., Caipang, C. M. A., Kiron, V., Rombout, J. H. W. M., \& Brinchmann, M. F. (2011). Proteome reference map of the skin mucus of Atlantic cod (Gadus morhua) revealing immune competent molecules. Fish \& Shellfish Immunology, 31(2), 224-231. 
Rajanbabu, V., \& Chen, J.-Y. (2011). Applications of antimicrobial peptides from fish and perspectives for the future. Peptides, 32(2), 415-420. https://doi.org/10.1016/j.peptides.2010.11.005

Ravichandran, S., Kumaravel, K., Rameshkumar, G., \& Ajithkumar, T. T. (2010). Antimicrobial peptides from the marine fishes. Research Journal of Immunology, 3(2), 146-156. https://doi.org/10.3923/rji.2010.146.156

Roberts, T. R. (1989). The freshwater fishes of Western Borneo (Kalimantan Barat, Indonesia) / by Tyson R. Roberts. Version details - Trove. San Francisco: California Academy of Sciences, 1989. https://doi.org/500 s 597.176/09598/3

Ross, N., Firth, K., Wang, A., Burka, J., \& Johnson, S. (2000). Changes in hydrolytic enzyme activities of naïve Atlantic salmon Salmo salar skin mucus due to infection with the salmon louse Lepeophtheirus salmonis and cortisol implantation. Diseases of Aquatic Organisms, 41(1), 4351. https://doi.org/10.3354/dao041043

Sakurai, A., Sakamoto, Y., Mori, F., \& Loiselle, P. V. (1993). Aquarium fish of the world: the comprehensive guide to 650 species. Chronicle Books.

Saurabh, S., \& Sahoo, P. K. (2008). Lysozyme: an important defence molecule of fish innate immune system. Aquaculture Research, 39(3), 223-239. https://doi.org/10.1111/j.1365-2109.2007.01883.x

Song, R., Wei, R.-B., Luo, H.-Y., \& Wang, D.-F. (2012). Isolation and Characterization of an Antibacterial Peptide Fraction from the Pepsin Hydrolysate of Half-Fin Anchovy (Setipinna taty). Molecules, 17(3), 2980-2991. https://doi.org/10.3390/molecules17032980

Subramanian, S., MacKinnon, S. L., \& Ross, N. W. (2007). A comparative study on innate immune parameters in the epidermal mucus of various fish species. Comparative Biochemistry and Physiology Part B: Biochemistry and Molecular Biology, 148(3), 256-263. https://doi.org/10.1016/J.CBPB.2007.06.003

Ullal, A. J., \& Noga, E. J. (2010). Antiparasitic activity of the antimicrobial peptide $\mathrm{Hb} \beta \mathrm{P}-1$, a member of the $\beta$ haemoglobin peptide family. Journal of Fish Diseases, 33(8), 657-664. https://doi.org/10.1111/j.13652761.2010.01172.x

Uthayakumar, V., Ramasubramanian, V., Senthilkumar, D., Priyadarisini, V. B., \& Harikrishnan, R. (2012). Biochemical characterization, antimicrobial and hemolytic studies on skin mucus of fresh water spiny eel Mastacembelus armatus. Asian Pacific Journal of Tropical Biomedicine, 2(2), S863-S869. https://doi.org/10.1016/S2221-1691(12)60325-6

Yeaman, M. R., \& Yount, N. Y. (2003). Mechanisms of antimicrobial peptide action and resistance. Pharmacological Reviews, 55(1), 27-55.

Yi, Y., You, X., Bian, C., Chen, S., Lv, Z., Qiu, L., \& Shi, Q. (2017). High-throughput identification of antimicrobial peptides from amphibious mudskippers. Marine Drugs, 15(11), 364.

Zhao, H., Yang, H., Sun, J., Chen, Y., Liu, L., Li, G., \& Liu, L. (2016). The complete mitochondrial genome of the Anabas testudineus (Perciformes, Anabantidae). Mitochondrial DNA Part A, 27(2), 1005-1007.

Zhao, X., Findly, R. C., \& Dickerson, H. W. (2008). Cutaneous antibody-secreting cells and B cells in a teleost fish. Developmental \& Comparative Immunology, 32(5), 500508. https://doi.org/10.1016/J.DCI.2007.08.009 